\title{
Effects of Dietary Carbohydrate To Lipid Ratios On Growth Performance, Body Composition, Serum Biochemical Indexes, Lipid Metabolism And Gene Expression of Central Appetite Regulating Factors In Chinese Perch (Siniperca Chuatsi)
}

\section{Di Peng}

Huazhong Agricultural University: Huazhong Agriculture University

Xu-Fang Liang ( $\nabla$ xufang_liang@hotmail.com )

Huazhong Agricultural University: Huazhong Agriculture University

\section{Farui Chai}

Huazhong Agricultural University: Huazhong Agriculture University

\section{Hexiong Feng}

Huazhong Agricultural University: Huazhong Agriculture University

Jiao Li

Huazhong Agricultural University: Huazhong Agriculture University

\section{Shulin Tang}

Huazhong Agricultural University: Huazhong Agriculture University

Ke Lu

Huazhong Agricultural University: Huazhong Agriculture University

\section{Qiwei Zhang}

Huazhong Agricultural University: Huazhong Agriculture University

\section{Research Article}

Keywords: Chinese perch (Siniperca chuatsi), CHO:L ratio, Lipid metabolism, Appetite

Posted Date: August 10th, 2021

DOI: https://doi.org/10.21203/rs.3.rs-758001/v1

License: (c) (i) This work is licensed under a Creative Commons Attribution 4.0 International License. Read Full License 


\section{Abstract}

An 8-week feeding trial was conducted to evaluate the effects of dietary carbohydrate to lipid (CHO: L) ratios on growth performance, body composition, serum biochemical indexes, lipid metabolism and gene expression of central appetite regulating factors in Chinese perch (Siniperca chuatsi) (mean initial weight: $12.86 \pm 0.10 \mathrm{~g}$ ). Five isonitrogenous and isoenergetic diets (fish meal, casein as main protein sources) were formulated to contain different graded $\mathrm{CHO}$ : $\mathrm{L}$ ratio diets ranging from $0.12,0.86,1.71,3.29$ and 7.19. Each diet was assigned to triplicate groups of 18 experimental fish for 8 weeks. Our results revealed that final body weight (FBW), weight gain rate (WGR), specific growth rate (SGR), protein efficiency ratio (PER) increased with dietary CHO:L ratio from 0.12 to 1.71 , and then decreased with further increases in dietary $\mathrm{CHO}: \mathrm{L}$ ratio. A two-slope broken-line regression analysis based on WGR showed that the optimal dietary $\mathrm{CHO}$ : $\mathrm{L}$ level for maximum growth performance of fish was 1.60. Crude lipid and crude protein content in the liver and glycogen concentration in the muscle and liver were significantly influenced by the dietary $\mathrm{CHO}: \mathrm{L}$ ratios $(P<0.05)$. The lowest crude lipid content in the liver was observed in fish fed the diet with a $\mathrm{CHO}: \mathrm{L}$ ratio of $1.71(P<0.05)$. Dietary $\mathrm{CHO}: \mathrm{L}$ ratios significantly induced the Glu contents of serum $(P<0.05)$. The relative expression levels of genes involved in lipid metabolism, such as srebp1 and fas in the liver showed a trend of first decreased and then increased with the increase of dietary CHO:L ratios levels. Appropriate $\mathrm{CHO}: \mathrm{L}$ ratio in the diet can effectively reduce the accumulation of liver fat. We observed in fish fed the $1.71 \mathrm{CHO}: \mathrm{L}$ ratio diet showed higher feed intake, up-regulated mRNA expression of neuropeptide Y (NPY) and agouti gene-related protein (AGRP), down-regulated mRNA expression of cocaine-and amphetamine-regulated transcript (CART) and pro-opiomelanocorticoid (POMC) significantly as compared to control group. Thus, these results provide the theoretical basis for feed formulation to determine the appropriate $\mathrm{CHO}: \mathrm{L}$ ratio requirement of Chinese perch.

\section{Introduction}

Over the past three decades, the growth rate of global aquaculture production is significantly higher than that of fishing, and it is the fastest growing industry in the global agricultural sector. Fish meal has become an important means to meet the demand for protein of aquatic animals and land animals. However, the demand for human consumption of fish is also increasing, resulting in high costs and fluctuations in fishmeal supply(FAO 2018, Montoya-Camachoet al 2019). To address this issue, in addition to constantly seeking high-quality protein sources that can replace fish meal, researchers are also improving feed formulation to save protein and improve feed protein efficiency(Turchiniet al 2009). Lipids and carbohydrates are one of the most important nutrients for organisms, and carbohydrates are a relatively inexpensive source of energy (Gaoet al 2018). Previous results demonstrate that appropriate lipid and carbohydrate levels in diets can provide energy to organisms and have the effect of saving protein(Hongyanet al 2019, Misraet al 2005, Sehrishet al 2020, Zhaoet al 2020). Lipids provide essential fatty acids for the growth and development of fish, are the main structure of cell membranes, and facilitate the transport and absorption of fat-soluble vitamins in the body (Xuet al 2020, Zhaokunet al 2020). Carbohydrates also have good adhesion and expandability, which can improve the stability of 
feed in water(Shi-Meiet al 2018). Excessive lipid will cause a series of problems such as physiological metabolic disorders, poor growth and fatty liver (Luet al 2014, Zhouet al 2020). Fish are also born with diabetes, especially carnivorous fish (Wilson 1994), Excessive carbohydrate level will lead to excessive metabolic burden, long-term hyperglycemia, excessive accumulation of liver glycogen, decreased immune function and other obstacles (Kamalamet al 2016, Shi-Meiet al 2018). In fish, glucose is closely related to lipid metabolism. Dihydroxyacetone phosphate produced in the process of glycolysis is then converted into glycerol needed for fat synthesis. Acetyl CoA generated from glucose oxidative decomposition is also a precursor for fatty acid synthesis, which can promote the generation of fat in the body (Liet a/ 2020). Dietary lipid can also be converted to glucose by gluconeogenesis. (Honoratoet al 2010). Fish appetite is co-regulated by the central system and the peripheral system, through the signal transduction between various appetite regulating factors (including appetite promoting factors and appetite suppressant factors), the "appetite regulating network" of fish is formed(Het al 2005, Yokoboriet al 2012). Food intake is closely related to appetite, and there is evidence in humans, other mammals and fish that the intake of a high-fat diet can suppress appetite and reduce sensitivity to the present food (bet a/2017, Liet al 2016, Ortinauet al 2014, Rasmussenet al 2015). In bony fish, fed high carbohydrate diet or injecting glucose intraperitoneally caused rainbow trout (Oncorhynchus mykiss) (Figueiredo-Silvaet al 2013), sea bass (Dicentrarchus labrax) (Castroet al 2015b), and Japanese flounder (Paralichthys olivaceus) (Liuet al 2018) decreased appetite and food intake. In recent years, researchers have made a high number of studies on the effects of dietary $\mathrm{CHO}: \mathrm{L}$ ratio on growth performance, feed utilization and antioxidant capacity of fish (Gaoet al 2010, Liet al 2012b, Zhouet al 2016). Nevertheless, there are few studies on the effects of different dietary $\mathrm{CHO}: \mathrm{L}$ ratios on lipid metabolism and appetite of fish.

The Chinese perch, which is mainly distributed in China, Russia, Korea, Vietnam and other regions, is one of the unique freshwater aquaculture fish with great economic value in China (Liu et al 2020a). It is a typical carnivorous fish with fierce feeding habits. It hunts live prey fish from its mouth-opening and could stably accept artificial compound feed after domestication (Lianget al 2010, Lianget a/ 2001). Currently, the protein content in the commercial feed of Chinese perch is extremely high, so changing the $\mathrm{CHO}: \mathrm{L}$ ratios in the diet to improve the utilization rate of protein of Chinese perch, reduce the content of fish meal, and thus reduce the feed cost is of great significance for intensive farming. In fact, there are relatively few studies on nutritional requirements of Chinese perch. This study aims to explore the effects of different dietary $\mathrm{CHO}: \mathrm{L}$ ratios on growth performance, body composition, liver lipid metabolism, liver histomorphology and appetite of Chinese perch. The results of this study may provide a basis for the development of high efficiency compound feed in the future.

\section{Materials And Methods}

All animal care and experimental procedures in the present study were approved by Huazhong Agricultural University and conducted in accordance with the Guidelines for Experimental Animals (Ethical code: HZAUFI-2020-0004).

\subsection{Experimental diets}


The formulation and proximate composition of the experimental diets are provided in Table 1. Five isonitrogenous and isoenergetic experimental diets were formulated to contain different levels of $\mathrm{CHO}: \mathrm{L}$ ratio $(0.12,0.86,1.71,3.29$ and 7.19$)$. Experimental diets were compounded with fish meal and casein as main protein sources, fish oil and soybean oil as main lipid sources, and dextrin as a carbohydrate source. All dry ingredients were thoroughly mixed in a mixer before the addition of oil and $40 \%$ water.

Then, the mixture was then pelleted ( $4 \mathrm{~mm}$ diameter) by a laboratory pelleting machine (HR 2330 model, PHILIPS, Suzhou, China). The soft pellets were placed in hermetic bags were stored in a freezer at $-20^{\circ} \mathrm{C}$ until used. 
Table 1

Formulation and proximate chemical compositions of the tested diets.

\begin{tabular}{|c|c|c|c|c|c|}
\hline \multicolumn{6}{|c|}{ Dietary C/L levels (\%) } \\
\hline Ingredients (\%) & D1 & $\mathrm{D} 2$ & D3 & D4 & D5 \\
\hline Fish meal & 46 & 46 & 46 & 46 & 46 \\
\hline Casein & 18 & 18 & 18 & 18 & 18 \\
\hline Dextrin & 4 & 10 & 16 & 22 & 28 \\
\hline Fish oil & 5.5 & 4.2 & 2.9 & 1.6 & 0.3 \\
\hline Soybean oil & 5.5 & 4.2 & 2.9 & 1.6 & 0.3 \\
\hline Vitamin supplement $^{1}$ & 1 & 1 & 1 & 1 & 1 \\
\hline Mineral supplement ${ }^{2}$ & 2 & 2 & 2 & 2 & 2 \\
\hline Sodium alginate & 2 & 2 & 2 & 2 & 2 \\
\hline Cellulose & 14 & 10.6 & 7.2 & 3.8 & 0.4 \\
\hline \multicolumn{6}{|l|}{ Proximate Compositions } \\
\hline Dry matter (\% DM) & 93.68 & 93.60 & 93.53 & 93.23 & 92.92 \\
\hline Crude protein (\% DM) & 48.64 & 47.82 & 48.57 & 48.35 & 48.13 \\
\hline Crude lipid (\% DM) & 14.62 & 11.49 & 8.97 & 6.53 & 3.85 \\
\hline Crude ash (\% DM) & 12.79 & 12.30 & 12.51 & 12.19 & 12.74 \\
\hline Energy $\left(\mathrm{MJ} \cdot \mathrm{kg}^{-1}\right)^{3}$ & 17.55 & 17.53 & 17.65 & 17.68 & 17.64 \\
\hline Crude fiber (\% DM) & 15.91 & 12.08 & 8.10 & 4.69 & 0.53 \\
\hline Nitrogen-free extract (\% DM) & 1.72 & 9.91 & 15.38 & 21.47 & 27.67 \\
\hline Carbohydrate: lipid (CHO:L) & 0.12 & 0.86 & 1.71 & 3.29 & 7.19 \\
\hline \multicolumn{6}{|c|}{$\begin{array}{l}\text { 1. Vitamin premix: choline, } 1000 \mathrm{mg} / \mathrm{kg} \text {; inositol, } 600 \mathrm{mg} / \mathrm{kg} ; \text { vitamin } \mathrm{A}, 40 \mathrm{mg} / \mathrm{kg} \text {; vitamin D3, } 60 \\
\mu \mathrm{g} / \mathrm{kg} \text {; vitamin E, } 200 \mathrm{mg} / \mathrm{kg} \text {; vitamin K3, } 10 \mathrm{mg} / \mathrm{kg} \text {; vitamin B1 (thiamin), } 15 \mathrm{mg} / \mathrm{kg} \text {; vitamin B2 } \\
\text { (riboflavin), } 25 \mathrm{mg} / \mathrm{kg} \text {; vitamin B6, } 20 \mathrm{mg} / \mathrm{kg} \text {; pantothenic acid calcium, } 50 \mathrm{mg} / \mathrm{kg} \text {; niacinamide, } 200 \\
\mathrm{mg} / \mathrm{kg} \text {; biotin, } 3.2 \mathrm{mg} / \mathrm{kg} \text {; vitamin B12, } 0.1 \mathrm{mg} / \mathrm{kg} \text {; folic acid, } 10 \mathrm{mg} / \mathrm{kg} \text {; ascorbic acid, } 210 \mathrm{mg} / \mathrm{kg} \text {. }\end{array}$} \\
\hline \multicolumn{6}{|c|}{$\begin{array}{l}\text { 2. Mineral premix: CaHPO4, } 15 \mathrm{~g} / \mathrm{kg} ; \mathrm{KCl}, 3 \mathrm{~g} / \mathrm{kg} ; \mathrm{MgSO} 4,0.8 \mathrm{~g} / \mathrm{kg} ; \mathrm{NaCl}, 1.5 \mathrm{~g} / \mathrm{kg} ; \mathrm{CuSO} 4 \cdot 5 \mathrm{H} 2 \mathrm{O}, 10 \\
\mathrm{mg} / \mathrm{kg} ; \mathrm{FeSO} 4,150 \mathrm{mg} / \mathrm{kg} ; \mathrm{ZnSO} 4,80 \mathrm{mg} / \mathrm{kg} ; \mathrm{MnSO} 4,13 \mathrm{mg} / \mathrm{kg} ; \mathrm{Na} 2 S \mathrm{SeO} 3,0.7 \mathrm{mg} / \mathrm{kg} ; \mathrm{Kl}, 1.1 \mathrm{mg} / \mathrm{kg} ; \\
\mathrm{Na} 2 \mathrm{MoO} 4,0.14 \mathrm{mg} / \mathrm{kg} \text {; CoSO4, } 0.02 \mathrm{mg} / \mathrm{kg} ; \mathrm{KF} 0.26 \mathrm{mg} / \mathrm{kg} .\end{array}$} \\
\hline \multicolumn{6}{|c|}{$\begin{array}{l}\text { 3. Gross energy was calculated using energy equivalents } 18.81,35.57 \text {, and } 14.59 \mathrm{~kJ} / \mathrm{g} \text { for protein, } \\
\text { lipid and digestible carbohydrate, respectively }\end{array}$} \\
\hline
\end{tabular}

2.2. Experimental fish and feeding management 
The experiment was conducted in an indoor aquarium system at the Chinese Perch Research Center, Huazhong Agricultural University, Wuhan, China. About 500 Chinese perch were purchased from Wuhongshan Breeding Base (Chibi, China). Before the feeding experiment, Chinese perch were trained to accept the artificial diet according to the method of Liang et al. (2001). After acclimatization, 270 fish (mean initial weight: $12.86 \pm 0.10 \mathrm{~g}$ ) with uniform size, accepts artificial diet well and health were randomly assigned to 15 tanks with 18 fish per tank. Fish were hand-fed twice (08:00 and 19:00) fed till satiation daily. The amount of feed being consumed by fish in each tank was recorded daily. Uneaten feed was collected by siphoning after 15 -min feeding and then oven-dried at $60 \circ \mathrm{C}$ to calculate feed intake. During the feeding period, the water temperature, $\mathrm{pH}$, and dissolved oxygen (DO) level were $19-23$ $\circ C$, 7.1-7.5, and $>5 \mathrm{mg} / \mathrm{L}$, respectively. Ordinary photoperiod applied throughout the experiment.

\subsection{Sample collection and analysis}

After 8 weeks of feeding trial, all fish were starved for $24 \mathrm{~h}$, and then counted individually and weighed. Six fish were randomly selected from each replicate were anaesthetized with 3-aminobenzoic acid ethyl ester methane sulphonate (MS-222, $50 \mathrm{mg} / \mathrm{L}$ water). The blood was obtained from caudal vein of fish by syringe using a $1-\mathrm{mL}$ syringe and pooled into a sterile centrifuge tube to clot overnight at $4 \circ \mathrm{C}$, then centrifuged at $4000 \times \mathrm{g}$ at $4 \circ \mathrm{C}$ for $20 \mathrm{~min}$ to separate the serum and stored at $-80^{\circ} \mathrm{C}$ until used for analysis. Then these fish were dissected on ice to obtain brain, muscle, liver, intestine, mesentery and visceral adipose, quickly frozen in liquid nitrogen and cryopreserved at $-80 \circ \mathrm{C}$ for subsequent analysis. Liver tissues from three fishes from each group were collected and immediately fixed by $4 \%$ paraformaldehyde for histological evaluation. Another 3 fish were randomly chosen from each tank for whole-body composition.

The data were analysed for Weight Gain Rate (WGR), Specific Growth Rates (SGR), Hepatosomatic index $(\mathrm{HSI})$, Viscera index (VSI), Mesentery fat index (MFI), Survival Ratio (SR), Feed intake (FI) and Food Conversion Ratio (FCR) using the following formula:

Weight gain rate $($ WGR, \%) $=100 \times$ (final weight-initial weight)/initial weight

Specific growth rate $(S G R, \% / d)=100 \times($ In final weight - In initial weight $) /$ days

Hepatosomatic index $(\mathrm{HSI}, \%)=100 \times$ hepatopancreas weight/body weight

Viscera index $(\mathrm{VSI}, \%)=$ viscera weight $\times 100 /$ body weight

Mesentery fat index $(\mathrm{MFI}, \%)=$ the weight of mesenteric fat $/$ body weight

Survival rate $(\mathrm{SR}, \%)=100 \times$ final number of fish/initial number of fish

Food intake $\left(\mathrm{Fl}, \mathrm{g}\right.$ fish ${ }^{-1}$ days $\left.^{-1}\right)=$ total amount of the feed consumed $/$ number of fish/days

Feed conversion ratio $(\mathrm{FCR}, \%)=$ amount of feed given / weight gain 
Crude protein, crude lipid, ash and moisture of diets, whole body, muscle, and liver were measured according to standard Association of Official Agricultural Chemists methods(International and Technology 1995). Crude protein content was determined by measuring nitrogen $(N \times 6.25)$ levels using the Kjeldahl method following acid digestion with an auto Kjeldahl System (Kjelflex K-360; BUCHI Labortechnik AG, Flawil, Switzerland). Moisture content was measured by freeze-drying samples for $48 \mathrm{~h}$ in a vacuum freeze dryer (Christ Beta 2-4 LD plus LT, Marin Christ Corporation, Osterode, Germany). Ash level was examined through incineration at $550 \circ \mathrm{C}$ for $24 \mathrm{~h}$ in a muffle furnace.

Serum total protein (TP), albumin (ALB), glucose (GLU), total cholesterol (TCHO), triglycerides (TG), highdensity lipoprotein (HDLC) and low-density lipoprotein (LDLC) contents, along with aspartate transaminase (AST) and alanine transaminase (ALT) activities were determined using an automatic biochemical analyser (CHEMIX-800, Sysmex Corporation, Kobe, Japan) with commercial diagnostic reagent kits (Sysmex Wuxi Co. Ltd., Wuxi, China).

Total RNA was extracted by RNAiso Plus reagent (Takara, Dalian, China) manually, and the purity and quantity of RNA were determined by agarose gel electrophoresis, protein, and nucleic acid analyser. Then $1 \mu \mathrm{g}$ of total RNA was used for reverse transcription with HiScript ${ }^{\circledR}$ II Reverse Transcriptase (Code no. R301-01/02; Vazyme, China) in a $20 \mu \mathrm{L}$ reaction volume to synthesize cDNA. Specific primers for the candidate genes used for qPCR were designed based on previous published research paper of our laboratory (Table 2). Rpl13a gene was used as an endogenous reference to normalize the template amount. The total volume of the qRT-PCR reaction system was $20 \mu \mathrm{l}$, including $10 \mu \mathrm{l}$ of SYBR Green dye (Code no. Q311-02; Vazyme, China), $0.4 \mu \mathrm{l}$ of PCR forward/re-verse primers $(10 \mu \mathrm{M}), 1 \mu \mathrm{l}$ of cDNA template and $8.2 \mu \mathrm{l}$ RNase-free $\mathrm{H}_{2} \mathrm{O}$. The qRT-PCR amplification programme was $95^{\circ} \mathrm{C}$ for $1 \mathrm{~min}$, followed by 40 cycles consisting of $95^{\circ} \mathrm{C}$ for $10 \mathrm{~s}$ and $57^{\circ} \mathrm{C}$ for $30 \mathrm{~s}$ and a melt curve step (from $95^{\circ} \mathrm{C}$, gradually reducing $0.5^{\circ} \mathrm{C} / \mathrm{s}$ to $57^{\circ} \mathrm{C}$, with data acquisition every $6 \mathrm{~s}$ ). The amplification efficiencies of control and target genes were approximately equal and ranged from 96.3-104.9\%. Gene expression levels were quantified relative to the expression of rpl13a using the optimized comparative $\mathrm{Ct}(2-\Delta \Delta \mathrm{Ct})$ value method. All amplifications were performed in triplicate for each RNA sample. 
Table 2

Primer sequences for the quantitative real-time PCR.

\begin{tabular}{|c|c|c|c|}
\hline Gene name & Primer & Sequence 5'-3' & Annealing temp $\left({ }^{\circ} \mathrm{C}\right)$ \\
\hline \multirow[t]{2}{*}{ acca } & $\operatorname{acc} \alpha-\mathrm{F}$ & TATGCCCACTTACCCAAATGC & \multirow[t]{2}{*}{58} \\
\hline & $\operatorname{acc} a-\mathrm{R}$ & TGCCACCATACCAATCTCGTT & \\
\hline \multirow[t]{2}{*}{ fas } & fas-F & ATGGAAATCACCCCTGTAATCTT & \multirow[t]{2}{*}{57} \\
\hline & fas- $R$ & CTTATCTGACTACGGAATGAATCG & \\
\hline \multirow[t]{2}{*}{ cpt1 } & cpt1-F & ATGGTGTATTGGCTGGAGTCT & \multirow[t]{2}{*}{57.5} \\
\hline & cpt1-R & CTGTGTGGTAGGTTTTCCTTGAT & \\
\hline \multirow[t]{2}{*}{ srebp 1} & Srebp1-F & СTCССTCСтTTCTGTCGGCTC & \multirow[t]{2}{*}{58} \\
\hline & Srebp1-R & TCATTTGCTGGCAGTCGTGG & \\
\hline \multirow[t]{2}{*}{ npy } & npy-F & GTTGAAGGAAAGCACAGACA & \multirow[t]{2}{*}{58} \\
\hline & npy-R & GCTCATAGAGGTAAAAGGGG & \\
\hline \multirow[t]{2}{*}{ agrp } & AgRP-F & GAGCCAAGCGAAGACCAGA & \multirow[t]{2}{*}{60} \\
\hline & AgRP-R & GCAGCACGGCAAATGAGAG & \\
\hline \multirow[t]{2}{*}{ pomc } & pomc-F & GGCTGAAGATGGTGTGTCTATG & \multirow[t]{2}{*}{58} \\
\hline & pomc-R & ACATGCAGAGGTGAATACAGTC & \\
\hline \multirow[t]{2}{*}{ cart } & cart-F & CGAACCTAACCAGTGAGAAG & \multirow[t]{2}{*}{56} \\
\hline & cart-R & GGGACAGTCGCACATCTT & \\
\hline \multirow[t]{2}{*}{ rp/13a } & rpl13a-F & TATCCССССАСССТАTGACA & \multirow[t]{2}{*}{59} \\
\hline & rpl13a-R & ACGCCCAAGGAGAGCGAACT & \\
\hline
\end{tabular}

\subsection{Statistical Analysis}

All data were analysed by the Statistical Software SPSS for Windows (v. 26). Data were described as means \pm SEM of triplicate group. The data were subjected to independence sample $t$ test to check the differences between control and experimental groups. Differences were considered significant at $P \leq$ 0.05 .

\section{Results}

3.1. Growth performance and feed utilization 
As show in Table 3, SR did not show significant difference among fish fed the different dietary treatments $(P>0.05)$. Fish fed D3 had the highest FBW, WGR and SGR $(P<0.05)$. PER in fish fed D3 was significantly higher than that in fish fed other diet $(P<0.05)$. FI was significantly affected by the dietary CHO:L ratios $(P<0.05)$, fish fed D3 was significantly higher than D1, D2, D4 groups. HSI and VSI in the D1 was significantly higher than that in the other groups $(P<0.05)$. The IPR of D4, D5 groups were significantly higher than that of D1, D2, D3 groups $(P<0.05)$. FCR exhibited an opposite trend as observed in WGR, with the lowest level in fish fed D3 group $(P<0.05)$.

Table 3

Growth parameters of Chinese perch fed the experimental diets.

\begin{tabular}{|c|c|c|c|c|c|}
\hline & \multicolumn{5}{|c|}{ Dietary C/L levels (\%) } \\
\hline & D1 & $\mathrm{D} 2$ & D3 & D4 & D5 \\
\hline IBW(g) & $14.29 \pm 0.27$ & $13.88 \pm 0.28$ & $13.47 \pm 0.65$ & $14.22 \pm 0.87$ & $14.19 \pm 0.06$ \\
\hline FBW(g) & $21.49 \pm 0.57^{a}$ & $31.22 \pm 1.42^{b}$ & $39.59 \pm 2.08^{c}$ & $30.51 \pm 1.50^{b}$ & $33.99 \pm 1.24^{b}$ \\
\hline WGR (\%) & $85.70 \pm 6.94^{\mathrm{a}}$ & $124.82 \pm 8.63^{b c}$ & $193.86 \pm 6.37^{d}$ & $114.86 \pm 4.79^{b}$ & $139.66 \pm 9.54^{c}$ \\
\hline SGR (\%/d) & $1.10 \pm 0.07^{a}$ & $1.44 \pm 0.07^{b}$ & $1.92 \pm 0.04^{c}$ & $1.36 \pm 0.04^{b}$ & $1.56 \pm 0.07^{b}$ \\
\hline PER & $0.81 \pm 0.02^{\mathrm{a}}$ & $1.17 \pm 0.10^{b}$ & $1.51 \pm 0.06^{c}$ & $1.14 \pm 0.08^{b}$ & $1.24 \pm 0.09^{b}$ \\
\hline $\mathrm{Fl}(\mathrm{g})$ & $0.56 \pm 0.03^{a b}$ & $0.55 \pm 0.01^{\mathrm{ab}}$ & $0.64 \pm 0.01^{c}$ & $0.53 \pm 0.02^{a}$ & $0.59 \pm 0.01^{b c}$ \\
\hline HSI (\%) & $2.71 \pm 0.28^{b}$ & $1.79 \pm 0.08^{\mathrm{a}}$ & $1.73 \pm 0.07^{a}$ & $1.84 \pm 0.10^{\mathrm{a}}$ & $1.66 \pm 0.07^{a}$ \\
\hline VSI (\%) & $11.56 \pm 0.58^{c}$ & $8.58 \pm 0.42^{\mathrm{a}}$ & $10.01 \pm 0.40^{b}$ & $8.35 \pm 0.28^{a}$ & $8.34 \pm 0.27^{a}$ \\
\hline IPR (\%) & $0.82 \pm 0.14^{b}$ & $0.98 \pm 0.12^{b}$ & $0.90 \pm 0.07^{b}$ & $0.51 \pm 0.05^{\mathrm{a}}$ & $0.31 \pm 0.05^{\mathrm{a}}$ \\
\hline SR (\%) & $100.00 \pm 0.00$ & $100.00 \pm 0.00$ & $100.00 \pm 0.00$ & $100.00 \pm 0.00$ & $100.00 \pm 0.00$ \\
\hline FCR & $2.57 \pm 0.07^{c}$ & $1.80 \pm 0.16^{b}$ & $1.39 \pm 0.05^{\mathrm{a}}$ & $1.85 \pm 0.14^{b}$ & $1.81 \pm 0.15^{\mathrm{b}}$ \\
\hline
\end{tabular}

Based on broken-line regression analysis of WGR, the dietary $\mathrm{CHO}: \mathrm{L}$ ratios for optimum growth of Chinese perch was 1.60 , corresponding to $15.38 \%$ of nitrogen-free extract and $8.97 \%$ of crude lipid respectively, belongs to the D3 group (Fig. 1).

\subsection{Proximate composition and glycogen content in tissues}

Effects of dietary CHO:L ratios on whole body, proximate composition and glycogen content of Chinese perch are listed in Table 4. The lipid content of whole body trended downward as dietary CHO:L ratios increased. There were no significant differences in moisture, crude protein and crude lipid contents of the 
muscle among all treatments $(P>0.05)$. Dietary $\mathrm{CHO}: \mathrm{L}$ ratios significantly affected the contents of crude protein and lipid in liver of Chinese perch $(P<0.05)$. Fish fed D3 had lower crude lipid content in liver than other groups, and significantly lower than D1 and D4 groups $(P<0.05)$.

Table 4

The body composition of whole fish and muscle of Chinese perch fed the experimental diets.

\section{Dietary C/L levels (\%)}

\begin{tabular}{|c|c|c|c|c|c|}
\hline & D1 & D2 & D3 & D4 & D5 \\
\hline \multicolumn{6}{|l|}{ Whole body } \\
\hline Moisture (\%) & $74.23 \pm 0.18$ & $73.98 \pm 0.68$ & $74.69 \pm 0.47$ & $74.98 \pm 0.43$ & $75.16 \pm 0.58$ \\
\hline Crude protein (\%) & $17.19 \pm 0.32$ & $17.50 \pm 0.37$ & $17.18 \pm 0.69$ & $16.69 \pm 0.65$ & $16.35 \pm 0.76$ \\
\hline Crude lipid (\%) & $\begin{array}{l}15.83 \pm \\
0.59^{\mathrm{ab}}\end{array}$ & $\begin{array}{l}17.54 \pm \\
2.41^{\mathrm{b}}\end{array}$ & $\begin{array}{l}15.56 \pm \\
1.84^{\mathrm{ab}}\end{array}$ & $\begin{array}{l}13.76 \pm \\
0.75^{\mathrm{ab}}\end{array}$ & $\begin{array}{l}11.36 \pm \\
1.93^{\mathrm{a}}\end{array}$ \\
\hline \multicolumn{6}{|l|}{ Muscle } \\
\hline Moisture (\%) & $77.95 \pm 0.77$ & $77.85 \pm 0.46$ & $79.32 \pm 0.17$ & $78.51 \pm 0.83$ & $79.22 \pm 0.25$ \\
\hline Crude protein (\%) & $19.44 \pm 0.45$ & $20.01 \pm 0.38$ & $18.40 \pm 0.72$ & $19.68 \pm 0.58$ & $18.55 \pm 1.03$ \\
\hline Crude lipid (\%) & $5.09 \pm 0.99$ & $4.17 \pm 0.63$ & $4.20 \pm 1.01$ & $2.95 \pm 0.39$ & $3.75 \pm 0.06$ \\
\hline $\begin{array}{l}\text { Muscle } \\
\text { glycogen } /(\mathrm{mg} / \mathrm{g})\end{array}$ & $3.12 \pm 0.10^{\mathrm{a}}$ & $3.11 \pm 0.11^{a}$ & $\begin{array}{l}3.42 \pm \\
0.22^{\mathrm{ab}}\end{array}$ & $\begin{array}{l}3.58 \pm \\
0.08^{b c}\end{array}$ & $3.81 \pm 0.04^{c}$ \\
\hline \multicolumn{6}{|l|}{ Liver } \\
\hline Moisture (\%) & $74.41 \pm 3.35$ & $69.49 \pm 0.71$ & $70.53 \pm 0.45$ & $71.31 \pm 0.97$ & $73.69 \pm 1.40$ \\
\hline Crude protein (\%) & $\begin{array}{l}11.68 \pm \\
1.48^{\mathrm{a}}\end{array}$ & $\begin{array}{l}15.03 \pm \\
1.31^{\mathrm{b}}\end{array}$ & $\begin{array}{l}15.02 \pm \\
0.43^{b}\end{array}$ & $\begin{array}{l}14.01 \pm \\
0.64^{\mathrm{ab}}\end{array}$ & $\begin{array}{l}16.03 \pm \\
0.39^{b}\end{array}$ \\
\hline Crude lipid (\%) & $\begin{array}{l}14.79 \pm \\
1.10^{\mathrm{b}}\end{array}$ & $\begin{array}{l}12.75 \pm \\
1.93^{\mathrm{ab}}\end{array}$ & $9.24 \pm 0.44^{a}$ & $\begin{array}{l}14.04 \pm \\
1.33^{\mathrm{b}}\end{array}$ & $\begin{array}{l}11.81 \pm \\
1.33^{\mathrm{ab}}\end{array}$ \\
\hline $\begin{array}{l}\text { Liver glycogen/ } \\
(\mathrm{mg} / \mathrm{g})\end{array}$ & $\begin{array}{l}26.90 \pm \\
1.17^{\mathrm{a}}\end{array}$ & $\begin{array}{l}39.55 \pm \\
2.63^{b}\end{array}$ & $\begin{array}{l}51.49 \pm \\
2.15^{\mathrm{c}}\end{array}$ & $\begin{array}{l}55.48 \pm \\
6.62^{\mathrm{c}}\end{array}$ & $\begin{array}{l}54.00 \pm \\
2.89^{\mathrm{c}}\end{array}$ \\
\hline
\end{tabular}

The muscle glycogen and liver glycogen had an increase trend with the increasing $\mathrm{CHO}: \mathrm{L}$ ratios level. The highest muscle glycogen content was observed in D5 group, and significantly higher than D1, D2 and D3 groups. There was no significant difference in liver glycogen content among D3, D4 and D5 groups $(P>$ $0.05)$.

3.3. Serum biochemical indices 
Dietary $\mathrm{CHO}: \mathrm{L}$ ratios significantly induced the contents of GLU (Table 5). TP and ALB were significantly influenced by dietary $\mathrm{CHO}: \mathrm{L}$ ratios, and it were the lowest in D3 among all groups, and was significantly lower than that in D1, D2 and D4 $(P<0.05)$. The highest concentration of TCHO and TG were found in fish fed a diet with the lowest CHO:L ratio. The activities of AST and ALT both increased with dietary $\mathrm{CHO}: \mathrm{L}$ ratios, showing a trend of first decreased and then increased, and reached the lowest in D3 group $(P<$ 0.05). As dietary CHO:L ratio increased, serum HDLC content was significantly decreased $(P<0.05)$. On the contrary, LDLC was not significantly influenced by dietary $\mathrm{CHO}: \mathrm{L}$ ratio $(P>0.05)$.

Table 5

Serum biochemical indexes of Chinese perch fed the experimental diets.

\begin{tabular}{|c|c|c|c|c|c|}
\hline & \multicolumn{5}{|c|}{ Dietary C/L levels (\%) } \\
\hline & D1 & $\mathrm{D} 2$ & D3 & D4 & D5 \\
\hline $\mathrm{TP}(\mathrm{g} / \mathrm{L})$ & $41.42 \pm 1.40^{c}$ & $40.70 \pm 1.52^{\mathrm{C}}$ & $\begin{array}{l}31.97 \pm \\
1.52^{\mathrm{a}}\end{array}$ & $38.24 \pm 1.66^{\mathrm{bc}}$ & $\begin{array}{l}35.63 \pm \\
1.48^{\mathrm{ab}}\end{array}$ \\
\hline $\operatorname{ALB}(\mathrm{g} / \mathrm{L})$ & $11.63 \pm 0.40^{\mathrm{bc}}$ & $11.86 \pm 0.4^{c}$ & $9.80 \pm 0.43^{a}$ & $11.86 \pm 0.46^{c}$ & $\begin{array}{l}10.50 \pm \\
0.31^{\mathrm{ab}}\end{array}$ \\
\hline $\mathrm{TCHO}(\mathrm{mmol} / \mathrm{L})$ & $8.18 \pm 0.22^{b}$ & $7.84 \pm 0.25^{b}$ & $6.42 \pm 0.23^{a}$ & $6.96 \pm 0.22^{\mathrm{a}}$ & $6.59 \pm 0.19^{a}$ \\
\hline $\mathrm{TG}(\mathrm{mmol} / \mathrm{L})$ & $8.77 \pm 0.37^{c}$ & $7.70 \pm 0.23^{b}$ & $\begin{array}{l}7.42 \pm \\
0.29^{\mathrm{ab}}\end{array}$ & $6.89 \pm 0.37^{\mathrm{ab}}$ & $6.70 \pm 0.21^{\mathrm{a}}$ \\
\hline $\mathrm{GLU}(\mathrm{mmol} / \mathrm{L})$ & $8.75 \pm 0.41^{a}$ & $9.34 \pm 0.43^{\mathrm{a}}$ & $\begin{array}{l}11.90 \pm \\
0.55^{b}\end{array}$ & $11.43 \pm 0.74^{b}$ & $11.77 \pm 0.46^{b}$ \\
\hline AST(U/L) & $\begin{array}{l}108.19 \pm \\
13.33^{c}\end{array}$ & $\begin{array}{l}65.45 \pm \\
12.43^{b}\end{array}$ & $\begin{array}{l}28.53 \pm \\
8.07^{a}\end{array}$ & $68.84 \pm 14.99^{b}$ & $\begin{array}{l}94.52 \pm \\
12.40^{c}\end{array}$ \\
\hline $\operatorname{ALT}(U / L)$ & $121.01 \pm 8.47^{d}$ & $79.11 \pm 5.49^{c}$ & $\begin{array}{l}30.08 \pm \\
3.29^{a}\end{array}$ & $\begin{array}{l}72.16 \pm \\
10.41^{\mathrm{bc}}\end{array}$ & $56.28 \pm 6.01^{b}$ \\
\hline $\mathrm{HDLC}(\mathrm{mmol} / \mathrm{L})$ & $0.98 \pm 0.04^{b}$ & $0.87 \pm 0.04^{b}$ & $0.67 \pm 0.04^{a}$ & $0.68 \pm 0.04^{\mathrm{a}}$ & $0.59 \pm 0.03^{a}$ \\
\hline LDLC(mmol/L) & $1.10 \pm 0.20$ & $1.26 \pm 0.26$ & $1.04 \pm 0.34$ & $1.05 \pm 0.22$ & $1.05 \pm 0.25$ \\
\hline
\end{tabular}

3.4. Relative expression of lipid metabolism-related genes in liver

The expressions of lipid metabolism-related genes in Chinese perch fed different dietary CHO:L ratios levels are presented in Fig. 2. The expression of srebp 1 and fas in the liver showed a trend of first decreased and then increased with the increase of dietary $\mathrm{CHO}: \mathrm{L}$ ratios. And the expressions of srebp 1 and fas in the liver were the lowest in the D3 group, which was significantly lower than the other groups $(P<0.05)$. Compared with the D1 group, the expression of acca in the liver of the other groups was 
significantly reduced, and there was no significant difference $(P>0.05)$. The expression level of $c p t-1$ in the liver of D3 and D5 group was significantly higher than that of D1 group $(P<0.05)$ (Fig. 3).

\subsection{Relative expression of appetite-related genes in hypothalamus}

Concerning appetite regulation-related genes are presented in Fig. 4 and Fig. 5. Compared with the D1 group, the expression of $n p y$ in the D2 and D3 groups was significantly increased $(P<0.05)$. The expression of agrp increased with the increase in the level of dietary $\mathrm{CHO}: \mathrm{L}$ ratios, showing a trend of first increased and then decreased. The expression levels of npy and agrp were the highest in the D3 group and were significantly higher than the other groups $(P<0.05)$. With the increase of dietary CHO:L ratios, the expression of cart decreased significantly compared with the D1 group $(P<0.05)$. The expression of pomc in the D2 and D3 groups were significantly lower than the other groups $(P<0.05)$.

\subsection{Histology analyses of liver section and determination of hepatocyte inflammation}

Figure 6 shows the oil red $O$ staining and H\&E staining of Chinese perch liver tissue fed with different levels of dietary CHO:L ratios diet. The Oil-red $\mathrm{O}$ staining confirmed that the number of red dots (lipid droplets) has exhibited no obvious difference among D2 and D4 group, but it increased sharply in D1 and D5 group. The D3 group had the least number of lipid droplets (Fig. 6A). H\&E staining confirmed that except for the D3 group, the liver cells of the other treatment groups showed more different numbers of small vacuoles, and the hepatocyte nuclei were squeezed to the edge (Fig. 6B). This means that the liver cells have different degrees of pathological reactions.

\section{Discussion}

In the present study, we provided direct evidence that dietary $\mathrm{CHO}: \mathrm{L}$ ratio of 1.71 advanced the growth performance of Chinese perch. At this point, the WGR, SGR and PER of the Chinese perch reach the maximum. When the dietary CHO:L ratio was 0.12 , the WGR, SGR and PER were all lower than those of the other groups. This indicates that a relatively low- or high- $\mathrm{CHO}: \mathrm{L}$ ratio diet not only depressed Chinese perch growth but also caused their poor feed utilization. Protein utilization efficiency can be improved by adjusting the ratio of carbohydrates to lipids in the feed. (Jobling 2012). Similar results were found in other carnivorous fish. Appropriate $\mathrm{CHO}: \mathrm{L}$ ratio was helpful for fish to exert synergistic effect in the utilization of carbohydrate and lipid, improve the utilization rate of feed, and thus promote growth. Such as large yellow croaker (Larimichthys crocea) (Zhouet al 2016), juvenile hybrid grouper (epinephelus fuscoguttatus $\square \times$ Epinephelus lanceolatus $\nabla$ )(Gaoet al 2018), juvenile cobia (Rachycentron canadum) (Zhaoet al 2020) and juvenile black seabream(Acanthopagrus schlegelii) (Sehrishet al 2020). 0.12 CHO:L group showed poor growth, indicating that high-lipid/low-carbohydrate group was not conducive to its growth, and its VSI and HSI were higher than those in other groups, indicating that higher dietary lipid level would affect lipid deposition in viscera and liver. (Zhouet al 2020). Polyline regression analysis based on WGR revealed that the dietary $\mathrm{CHO}$ : $L$ requirements of Chinese perch could be satisfied if the $\mathrm{CHO}: \mathrm{L}$ ratio reached 1.60. Growth, feed efficiency and protein utilization ratio suggest that carbohydrates are a better digestible energy source for Chinese perch compared with lipids and can save protein. 
Although the carbohydrate utilization capacity of carnivorous fish is weak, however, the carbohydrate utilization level of fish is a result of interactions with the physical state of dietary starch, molecular complexity, glucose tolerance, environment, temperature, and other nutrient elements in the feed (Braugeet al 1995, Hemreet al 2015, Liet al 2019b).

In this study, dietary $\mathrm{CHO}: \mathrm{L}$ ratio had no significant effect on muscle composition but had significant effect on crude lipid content of whole fish and liver. The lipid content of whole fish generally decreases and the lipid content of liver a decreasing trend first and then increasing trend in response to increasing dietary CHO: $\mathrm{L}$ ratio in feed. It indicates that the crude lipid content of whole body is positively correlated with the dietary lipid level, and excessive lipid will be deposited in fish body. However, fish have a poor ability to utilize carbohydrate. When the high-carbohydrate/low-lipid, fish may decompose part of the body lipid for energy supply, such as the lipid in muscle. Similar results were found in large yellow croaker (Larimichthys crocea)(Liet al 2019c) and golden pompano (Trachinotus ovatus)(Donget al 2018). In the liver, both high lipid levels and high carbohydrate levels contribute to fat deposition. These results were similar to those previously reported in largemouth bass (Micropterus salmoides) (Zhouet al 2020) and blunt snout bream (Megalobrama amblycephala) (Wanget al 2017).

The blood index parameters could indicate the physiological and health status of fish and could change dynamically with the nutritional status of fish (Fazio 2019). In this study, TG, TCHO, and HDLC in serum were significantly decreased with the increase of $\mathrm{CHO}$ : $\mathrm{L}$ ratio in the diet, indicating that endogenous lipid transport in fish was also more active under the high lipid diet. Metabolites rich in TG and CHO in liver were transported to other abdominal organs along with blood circulation, resulting in the increase of VSI. The serum Glu content was significantly increased with the dietary $\mathrm{CHO}$ : $\mathrm{L}$ ratio increasing. Liver glycogen significantly increased in the dietary $\mathrm{CHO}$ : $\mathrm{L}$ of 0.12 to 1.71 and then leveled off. The results show that the Chinese perch could use a certain level of carbohydrate $(<15.38 \%)$ in feed and store it in liver in the form of liver glycogen. However, the Chinese perch still cannot make good use of carbohydrate. When the dietary carbohydrate level is higher than $15.38 \%$, the serum Glu content increases continuously, leading to hyperglycemia and partial glycogen storage in the muscle. Similar results have been observed in some carnivorous fish(Mingchunet al 2011, Zhouet al 2016). Serum total protein content is a major indicator of physiological health of fish (Alexanderet al 2011). The albumin and globulin contained in it are generally considered to play an important role in the innate immune response of fish (Liet al 2012a, Wiegertjeset al 1996). ALT and AST are considered sensitive indicators of normal tissue function and are often used to determine whether the liver has been damaged(Xinget al 2020). In this study, when dietary CHO:L ratio was 1.71, TP, ALB, ALT and AST were significantly lower than those in other groups. These results indicate that high dietary fat or carbohydrate levels will affect the health of the fish, increase the burden on the liver, and thus activate the non-specific immunity of the fish. In some previous studies, such as European sea bass (Dicentrarchus labrax L.) (SitjÀ-Bobadilla and PÉRezSÁNchez 1999), blunt snout bream(Megalobrama amblycephala) (Zhouet al 2013) have been reported.

Lipid deposition in the liver is a comprehensive result of lipid uptake, transport, decomposition, and synthesis in hepatocytes(Cet al 2012, Xinget al 2020). srebp-1 is a transcription factor that can activate 
target genes of its downstream fatty acid synthesis(Kuiperset al 2011). fas and acca are important enzymes in fat synthesis, which are involved in the synthesis of fatty acids (Castroet al 2016). In this study, srebp-1 and fas showed a trend of decreasing first and then increasing with the increase of dietary $\mathrm{CHO}: \mathrm{L}$ ratio, indicating that fatty acid synthesis in liver was more active in the diet of high-lipid/lowcarbohydrate or high-carbohydrate/low-lipid. In addition, the increase of dietary carbohydrate level may also be the reason for the increase of liver srebp-1, which can also mediate the conversion of excess carbohydrates to fatty acids (Ferré and Foufelle 2010, Miriamet a/ 2008), fatty acids enter the liver and are esterified into triglycerides, which are stored in lipid droplets on the one hand and enter liver cells, On the other hand, as TG-rich metabolites, they are secreted into blood for circulation(Yuanet al 2016). However, serum TCHO, TG and LDLC levels did not increase in the high-carbohydrate/low-lipid group (D4 and D5), indicating that fatty acids may mainly exist in liver lipid droplets, which may cause harm to the health of fish. And $c p t-1$ is the key gene of fatty acid $\beta$ oxidation. The $c p t-1$ in liver of Chinese perch was significantly up-regulated when the dietary $\mathrm{CHO}: \mathrm{L}$ ratio is 1.71 , indicating that the $\beta$-oxidation of fatty acids is more active under this nutritional state. At this time, liver fat was significantly lower than that of the other groups, indicating that liver of Chinese perch can effectively alleviate liver fat accumulation by reducing fatty acid synthesis and increasing fatty acid $\beta$ oxidation when feeding appropriate $\mathrm{CHO}: \mathrm{L}$ ratio diet.

Feed is the main cost in aquaculture, so the feed intake is considerable important to the aquaculture of economic fish, and the feed intake is controlled by the central and peripheral appetite network system(Liet al 2019a, Marta and L. 2017). In previous studies, fish's appetite was influenced by the nutritional content of the feed and the proportion of different ingredients added. By Catarina Basto-Silva studies have shown that different dietary protein to energy ratio affects the feeding intake and appetite regulation of gilthead seabream(Sparus aurata)(Catarinaet al 2021). The central system, especially the hypothalamus, can sense the nutritional state of the body, regulate food intake and metabolism through different neural circuits, and maintain the energy homeostasis of the body(Clémence and J 2010). These circuits mainly include $n p y /$ agrp, pomc/ cart neurons, and central and peripheral endocrine factors that respond to circulating glucose, fatty acid, or amino acid levels, respectively(Blouet and Schwartz 2009, Efeyanet al 2015, Mobbset al 2005). In previous studies based on Chinese perch in our laboratory, central nervous system npy/ agrp was generally used as an appetite promoting factor, while pomc/ cart was used as an appetite suppressant factor (Liuet al 2020b). In this study, with the increase of dietary CHO:L ratio, the food intake of Chinese perch in D3 group was significantly higher than that in other treatment groups. The expression of $n p y /$ agrp neurons in the hypothalamus of Chinese perch was firstly increased and then decreased in response to increasing $\mathrm{CHO}: \mathrm{L}$ ratio in feed. However, the expression level of inhibitory appetite factor cart in D1 group was significantly higher than that in other treatment groups, and the expression level of pomc in D2 and D3 groups was significantly downregulated. These results indicated that high lipid or high carbohydrate diet could inhibit the expression of appetite promoting genes npy and agrp to some extent and promote the expression of appetite suppressing genes cart and pomc. In previous studies, high carbohydrate diets can induce European sea bass (Dicentrarchus labrax) (Castroet al 2015a), rainbow trout(Oncorhynchus mykiss) (Cristinaet al 2016), tilapia(Oreochromis mossambicus) 
(Otero-Rodinoet al 2016), and Siberian sturgeon(Acipenser baerii) (Gonget al 2015) reduced food intake. High lipid diets also decrease food intake of fish(Yong-Junet al 2018). Therefore, appropriate CHO:L ratio feed can promote appetite, which has a positive effect on increasing food intake to avoid anorexia in the process of breeding.

\section{Conclusion}

In conclusion, through broken line regression analysis, the optimal carbohydrate-to-lipid ratio in the diet of Chinese perch is recommended to be 1.71. The ratio of sugar to lipid in the diet affected the growth and feeding of Chinese perch, the antioxidant indexes in serum and the accumulation of glycogen in body. In addition, the appropriate carbohydrate-to-lipid ratio in the diet up-regulated or down-regulated the expression of lipid metabolism genes in the liver and reduced the lipid deposition in the liver. Appropriate $\mathrm{CHO}: \mathrm{L}$ ratio affects the transcription level of hypothalamus appetite gene, thus increasing food intake. The results of this study can provide an important reference for the optimization of compound feed for Chinese perch.

\section{Declarations}

\section{Acknowledgments}

D.P., and X-F L. designed the experiments and draft the manuscript. D.P., F-R C., and H-X F. performed the experiments. All authors read and approved the final manuscript.

\section{Data availability statement}

All data are available from the corresponding author by request.

\section{Ethics declarations}

All experiments and animal-handling procedures were approved by the Ethics Committee of the Institute of Laboratory Animal Centre, Huazhong Agriculture University (Ethical code: HZAUFI-2020-0004).

\section{Declaration of interests}

The authors declare that they have no known competing financial interests or personal relationships that could have appeared to influence the work reported in this paper.

\section{Funding statement}


This work was financially supported by China Agriculture Research System (CARS-46), the National Key R \& D Program of China (2019YFD0900500) and the National Natural Science Foundation of China (31972809).

\section{Conflict of Interest}

All authors of this research paper have directly participated in the planning, execution, or analysis of this study. No conflict of interest exits in the submission of this manuscript, and manuscript is approved by all authors for publication.

\section{References}

1. Alexander C, Sahu NP, Pal AK et al (2011) Haemato-immunological and stress responses of Labeo rohita (Hamilton) fingerlings: effect of rearing temperature and dietary gelatinized carbohydrate[J]. Journal of Animal Physiology Animal Nutrition 95(5):653-663

2. Frédéric Tantot a b, L P A B CS, C A R M B et al., The effect of high-fat diet consumption on appetitive instrumental behavior in rats[J]. Appetite, 2017, 108: 203-211

3. Blouet C, Schwartz GJ (2010) Hypothalamic nutrient sensing in the control of energy homeostasis. Behav Brain Res 209(1):1-12 PubMed, 209(1:1-12.

4. Brauge $C$, Corraze G, Médale F, Effects of dietary levels of carbohydrate and lipid on glucose oxidation and lipogenesis from glucose in rainbow trout, Oncorhynchus mykiss, reared in freshwater or in seawater [J]. Comparative Biochemistry \& Physiology Part A Physiology, 1995, 111(1):pp 117124

5. C SG (2012) S.O. V, and H.W. S, Fish oil - how does it reduce plasma triglycerides? [J]. BBA Molecular Cell Biology of Lipids 1821(5):843-851

6. Castro C, Corraze G, Basto A et al (2016) Dietary Lipid and Carbohydrate Interactions: Implications on Lipid and Glucose Absorption, Transport in Gilthead Sea Bream (Sparus aurata) Juveniles[J]. Lipids 51(6):1-13

7. Castro C, Corraze G, Pérez-Jiménez A et al (2015) Dietary carbohydrate and lipid source affect cholesterol metabolism of European sea bass (Dicentrarchus labrax) juveniles[J]. Br J Nutr 114(08):1143-1156

8. Catarina B-S, Paula E, Aires O-T et al., Dietary protein source and protein/carbohydrate ratio affects appetite regulation-related genes expression in gilthead seabream (Sparus aurata) - ScienceDirect[J]. Aquaculture, 2020, 533

9. Clémence B (2010) and S.G. J, Hypothalamic nutrient sensing in the control of energy homeostasis [J]. Behav Brain Res 209(1):1-12

10. Cristina O-R, Cristina V, Rosa Á-O et al., In vitro evidence supports the presence of glucokinaseindependent glucosensing mechanisms in hypothalamus and hindbrain of rainbow trout[J]. Journal 
of Experimental Biology, 2016: jeb.137737

11. Dong LF, Tong T, Zhang Q et al., Effects of dietary carbohydrate to lipid ratio on growth, feed utilization, body composition and digestive enzyme activities of golden pompano (Trachinotus ovatus) [J]. John Wiley \& Sons, Ltd (10.1111). 2018. 24(1)

12. Efeyan A, Comb WC, Sabatini DM (2015) Nutrient-sensing mechanisms, and pathways[J]. Nature 517(7534):302

13. FAO, The State of World Fisheries and Aquaculture 2018:Meeting the Sustainable Development Goals (2018) United Nations. 2018

14. Fazio F, Fish hematology analysis as an important tool of aquaculture: A review [J]. Aquaculture, 2019. 500

15. Ferré P, Foufelle F, Hepatic steatosis: a role for de novo lipogenesis and the transcription factor SREBP-1C.[J]. Diabetes Obesity \& Metabolism, 12

16. Figueiredo-Silva AC, Saravanan S, Schrama JW et al (2013) A comparative study of the metabolic response in rainbow trout and Nile tilapia to changes in dietary macronutrient composition[J]. Br $\mathrm{J}$ Nutr 109(05):816-826

17. Gao W, Liu YJ, Tian LX et al (2010) Effect of dietary carbohydrate-to-lipid ratios on growth performance, body composition, nutrient utilization and hepatic enzymes activities of herbivorous grass carp (Ctenopharyngodon idella) [J]. Aquac Nutr 16(3):327-333

18. Gao Y, Luo Y, Li X et al., Effects of dietary carbohydrate/lipid ratios on growth, feed utilization, hematology parameters, and intestinal digestive enzyme activities of juvenile hybrid grouper (BrownMarbled Grouper Epinephelus fuscoguttatus $\nabla \times$ Giant Grouper E. lanceolatus $\nabla)$ [J]. North American Journal of Aquaculture, 2018. 80(4)

19. Gong G, Xue M, Wang J et al., The regulation of gluconeogenesis in the Siberian sturgeon (Acipenser baerii) affected later in life by a short-term high-glucose programming during early life[J]. Aquaculture, 2015. 436

20. H V, F CL, U. S, et al., Neuropeptides and the control of food intake in fish[J]. General and comparative endocrinology, 2005. 142(1-2)

21. Hemre GI, Mommsen TP, Nutrition KJA (2015) Carbohydrates in fish nutrition: effects on growth, glucose metabolism and hepatic enzymes[J]. Aquac Nutr 8(3):175-194

22. Hongyan L, Wenjie X, Junyan J et al., Effects of Dietary Carbohydrate and Lipid Concentrations on Growth Performance, Feed Utilization, Glucose, and Lipid Metabolism in Two Strains of Gibel Carp[J]. Frontiers in veterinary science, 2019. 6

23. Honorato CA, Almeida LC, Nunes C et al (2010) Effects of processing on physical characteristics of diets with distinct levels of carbohydrates and lipids: the outcomes on the growth of pacu (Piaractus mesopotamicus)[J]. Aquac Nutr 16(1):91-99

24. International, AJ.T.i.FS, Technology, Official methods of analysis of AOAC International, 16th edition. Volume 2 (1995) 6(11): p. 382-382 
25. Jobling MJAl, National Research Council (NRC): Nutrient requirements of fish and shrimp. 2012. 20(3): p. $601-602$

26. Kamalam BS, Medale F, Panserat S (2017) Utilisation of dietary carbohydrates in farmed fishes: New insights on influencing factors, biological limitations and future strategies [J]. Aquaculture 467(1):327

27. Kuipers RS, Luxwolda MF, Sango WS et al (2011) Postpartum changes in maternal and infant erythrocyte fatty acids are likely to be driven by restoring insulin sensitivity and DHA status[J]. Med Hypotheses 76(6):794-801

28. Li A, Yuan X, Liang XF et al (2016) Adaptations of lipid metabolism and food intake in response to low and high fat diets in juvenile grass carp (Ctenopharyngodon idellus) [J]. Aquaculture 457:43-49

29. Li L, Fang J, Liang XF et al., Effect of feeding stimulants on growth performance, feed intake and appetite regulation of mandarin fish, Siniperca chuats[J]. Aquaculture Research, 2019(8)

30. Li S, Sang C, Wang A et al., Effects of dietary carbohydrate sources on growth performance, glycogen accumulation, insulin signaling pathway and hepatic glucose metabolism in largemouth bass, Micropterus salmoides [J]. Aquaculture (Amsterdam, Netherlands), 513:734391-734391

31. Li S, Yin J, Zhang $\mathrm{H}$ et al., Effects of dietary carbohydrate and lipid levels on growth performance, feed utilization, body composition and non-specific immunity of large yellow croaker (Larimichthys crocea) [J]. Aquaculture Nutrition, 2019, 25(5)

32. Li X-F, Liu W-B, Lu K-L et al., Dietary carbohydrate/lipid ratios affect stress, oxidative status and nonspecific immune responses of fingerling blunt snout bream, Megalobrama amblycephala[J]. Fish \& Shellfish Immunology, 2012, 33(2):pp 316-323

33. Li Z, Wen-Bin L (2020) B.P. B., et al., Utilization of raw and gelatinized starch by blunt snout bream Megalobrama amblycephala as evidenced by the glycolipid metabolism, glucose tolerance and mitochondrial function[J]. Aquaculture 529:735603

34. Liang X, Liu J, Huang B et al (2010) The role of sense organs in the feeding behaviour of Chinese perch[J]. J Fish Biol 52(5):1058-1067

35. Liang X, Oku H, Ogata H et al (2015) Weaning Chinese perch Siniperca chuatsi (Basilewsky) onto artificial diets based upon its specific sensory modality in feeding[J]. Aquac Res 32(s1):76-82

36. Liu D, Guo B, Han D et al., Comparatively study on the insulin-regulated glucose homeostasis through brain-gut peptides in Japanese flounder Paralichthys olivaceus after intraperitoneal and oral administration of glucose [J]. General and Comparative Endocrinology, 2018:9-20

37. Liu L, Fang J, Liang XF et al., Nucleotide promotes feed intake and protein utilization via regulating the gene expression of feeding and nitrogen metabolism in juvenile Chinese perch (Siniperca chuatsi)[J]. Aquaculture Nutrition. 2020b. 26(5)

38. Lu KL, Xu WN, Wang LN et al (2014) Hepatic $\beta$-Oxidation and Regulation of Carnitine Palmitoyltransferase (CPT) I in Blunt Snout Bream Megalobrama amblycephala Fed a High Fat Diet [J]. PLOS ONE 9(3):e93135- 
39. Marta CS and S.J. L., Nutrient Sensing Systems in Fish: Impact on Food Intake Regulation and Energy Homeostasis [J]. Frontiers in Neuroscience, 2017, 10

40. Mingchun R, Qinghui et al., Effect of dietary carbohydrate level on growth performance, body composition, apparent digestibility coefficient and digestive enzyme activities of juvenile cobia, Rachycentron canadum L[J]. Aquaculture Research, 2011, 42(10)

41. Miriam E, Isidoro M, Marlon C et al (2007) Role of Sp1 and SREBP-1a in the insulin-mediated regulation of glucokinase transcription in the liver of gilthead sea bream (Sparus aurata) [J]. Gen Comp Endocrinol 155(2):359-367

42. Misra S, Sahu NP, Pal AK et al (2006) Pre- and post-challenge immuno-haematological changes in Labeo rohita juveniles fed gelatinised or non-gelatinised carbohydrate with n-3 PUFA [J]. Fish Shellfish Immunol 21(4):346-356

43. Mobbs CV, Isoda F, Makimura H et al., Impaired glucose signaling as a cause of obesity and the metabolic syndrome: The glucoadipostatic hypothesis[J]. Physiology \& Behavior, 2005, 85(1):pp 323

44. Montoya-Camacho N, Marquez-Ríos E, Castillo-Yáñez FJ et al., Advances in the use of alternative protein sources for tilapia feeding[J]. Reviews in Aquaculture, 2019, 11(3)

45. Ortinau LC, Hoertel HA, Douglas SM et al (2014) Effects of high-protein vs. high- fat snacks on appetite control, satiety, and eating initiation in healthy women[J]. Nutr J 13(1):97

46. Otero-Rodino C, Velasco C, Alvarez-Otero R et al., In vitro evidence supports the presence of glucokinase-independent glucosensing mechanisms in hypothalamus and hindbrain of rainbow trout[J]. Journal of Experimental Biology, 2016: jeb.137737

47. Rasmussen $O$ (2015) Rnsholdt, et al., Manipulation of end-product quality in rainbow trout with finishing diets[J]. Aquac Nutr 6(1):17-23

48. Sehrish T, Misbah I, Min J et al (2020) Effects of Dietary Carbohydrate to Lipid Ratios on Growth Performance, Muscle Fatty Acid Composition, and Intermediary Metabolism in Juvenile Black Seabream (Acanthopagrus schlegelii) [J]. Front Physiol 11:507

49. Shi-Mei L, Chao-Ming S, Ming-Ming M et al (2018) Effect of high dietary starch levels on growth, hepatic glucose metabolism, oxidative status and immune response of juvenile largemouth bass, Micropterus salmoides[J], 78. Fish \& Shellfish Immunology, pp 121-126

50. SitjÀ-Bobadilla A, PÉRez-SÁNchez J, SHORT COMMUNICATION Diet related changes in non-specific immune response of European sea bass (Dicentrarchus labrax L.) [J]. Fish \& Shellfish Immunology, 1999, 9(8):pp 637-640

51. Turchini GM, Torstensen BE, Ng WK, Fish oil replacement in finfish nutrition [J]. John Wiley \& Sons, Ltd (10.1111). 2009. 1(1)

52. Wang B-K, Liu W-B, Xu C et al., Dietary carbohydrate levels and lipid sources modulate the growth performance, fatty acid profiles and intermediary metabolism of blunt snout bream Megalobrama amblycephala in an interactive pattern [J]. Aquaculture, 2017. 481 
53. Wiegertjes GF, Stet RM, Parmentier HK et al., Immunogenetics of disease resistance in fish: A comparative approach[J]. Developmental \& Comparative Immunology, 1996, 20(6):pp 365-381

54. Wilson RPJA (1994) Utilization of dietary carbohydrate by fish - ScienceDirect. [J] Aquaculture 124(1-4):67-80

55. Xing L, Di P, Xiaoru C et al., Effects of dietary protein levels on growth, muscle composition, digestive enzymes activities, hemolymph biochemical indices and ovary development of pre-adult red swamp crayfish (Procambarus clarkii) [J]. Aquaculture Reports, 2020. 18

56. Xu H, Han T, Li X et al (2020) Effects of dietary lipid levels on survival, growth performance, and antioxidant ability of the early juvenile Scylla paramamosain [J]. Aquaculture 528:735559

57. Yokobori E, Azuma M, Nishiguchi R et al (2012) Neuropeptide Y Stimulates Food Intake in the Zebrafish, Danio rerio[J]. J Neuroendocrinol 24(5):766-773

58. Yong-Jun D, Guang-Zhen J, Xiang-Yang Y et al., High-fat-diet-induced inflammation depresses the appetite of blunt snout bream (Megalobrama amblycephala) through the transcriptional regulation of leptin/mammalian target of rapamycin[J]. The British journal of nutrition, 2018. 120(12)

59. Yuan X, Liang X-F, Liu L et al., Fat deposition pattern and mechanism in response to dietary lipid levels in grass carp, Ctenopharyngodon idellus[J]. Fish Physiology and Biochemistry. 2016. 42(6)

60. Zhao H, Cao J, Chen X et al (2020) Effects of dietary lipid-to-carbohydrate ratio on growth and carbohydrate metabolism in juvenile cobia(Rachycentron canadum) [J]. Animal Nutrition 6(01):8084

61. Zhaokun D, Yongqiang L, Jinhua $\mathrm{H}$ et al., Dietary Lipid Supplementation Could Significantly Affect the Growth, Fatty Acid Profiles, and Expression of PPARa, Leptin, and Adiponectin Genes in Juvenile Genetically Improved Farmed Tilapia [J]. European Journal of Lipid Science and Technology. 2020. 123(1)

62. Zhou C, Liu B, Ge X et al (2013) Effect of dietary carbohydrate on the growth performance, immune response, hepatic antioxidant abilities and heat shock protein 70 expression of Wuchang bream, Megalobrama amblycephala[J]. J Appl Ichthyol 29(6):1348-1356

63. Zhou P, Wang M, Xie F et al., Effects of dietary carbohydrate to lipid ratios on growth performance, digestive enzyme and hepatic carbohydrate metabolic enzyme activities of large yellow croaker (Larmichthys crocea) [J] Aquaculture, 2016. 452

64. Zhou Y-L, Guo J-L, Tang R-J et al., High dietary lipid level alters the growth, hepatic metabolism enzyme, and anti-oxidative capacity in juvenile largemouth bass Micropterus salmoides [J]. Fish Physiology and Biochemistry, 2020. 46(1)

\section{Figures}




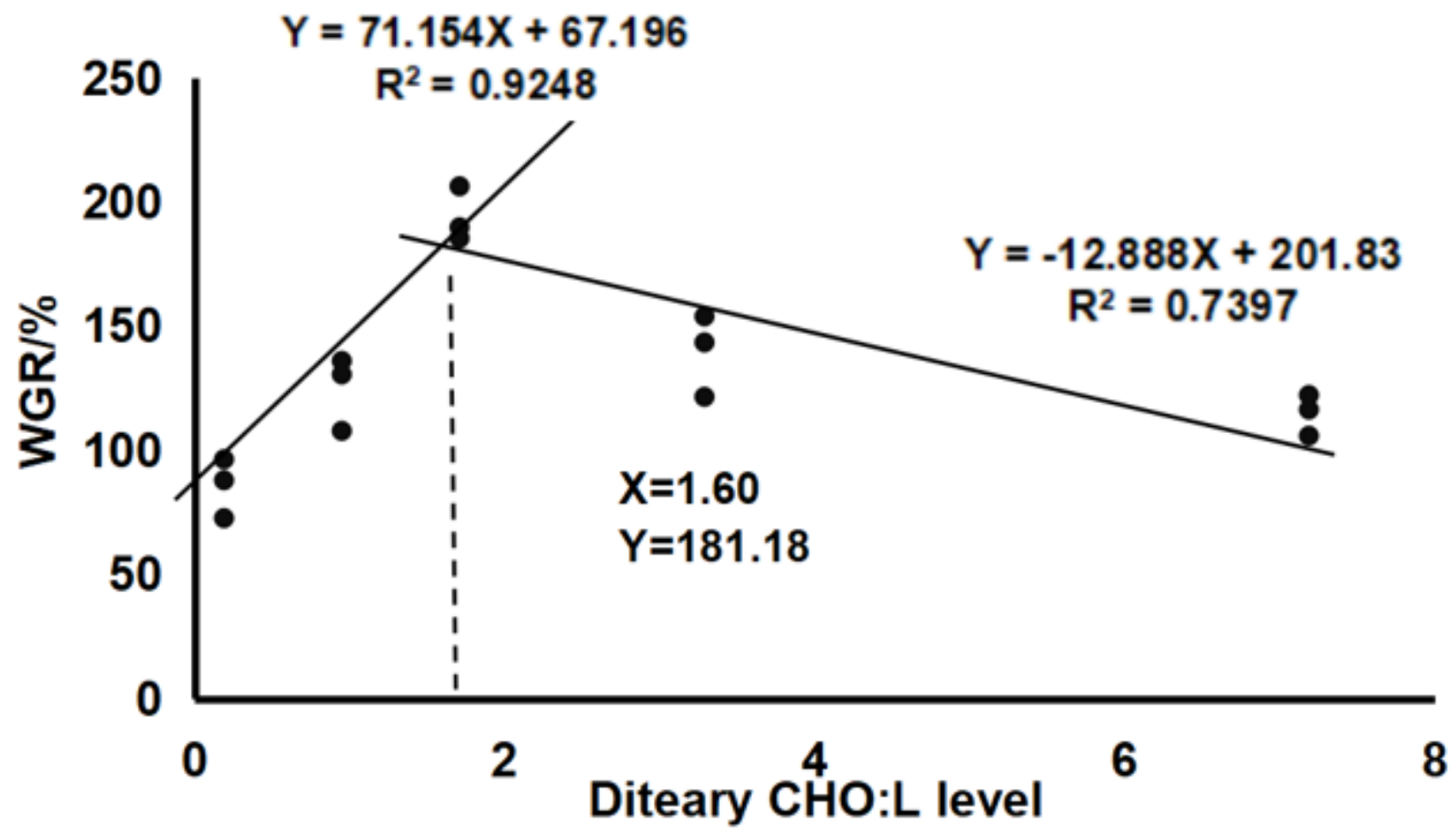

Figure 1

Broken-line analysis between the weight gain rate (WGR) of Chinese perch and dietary CHO: L level.

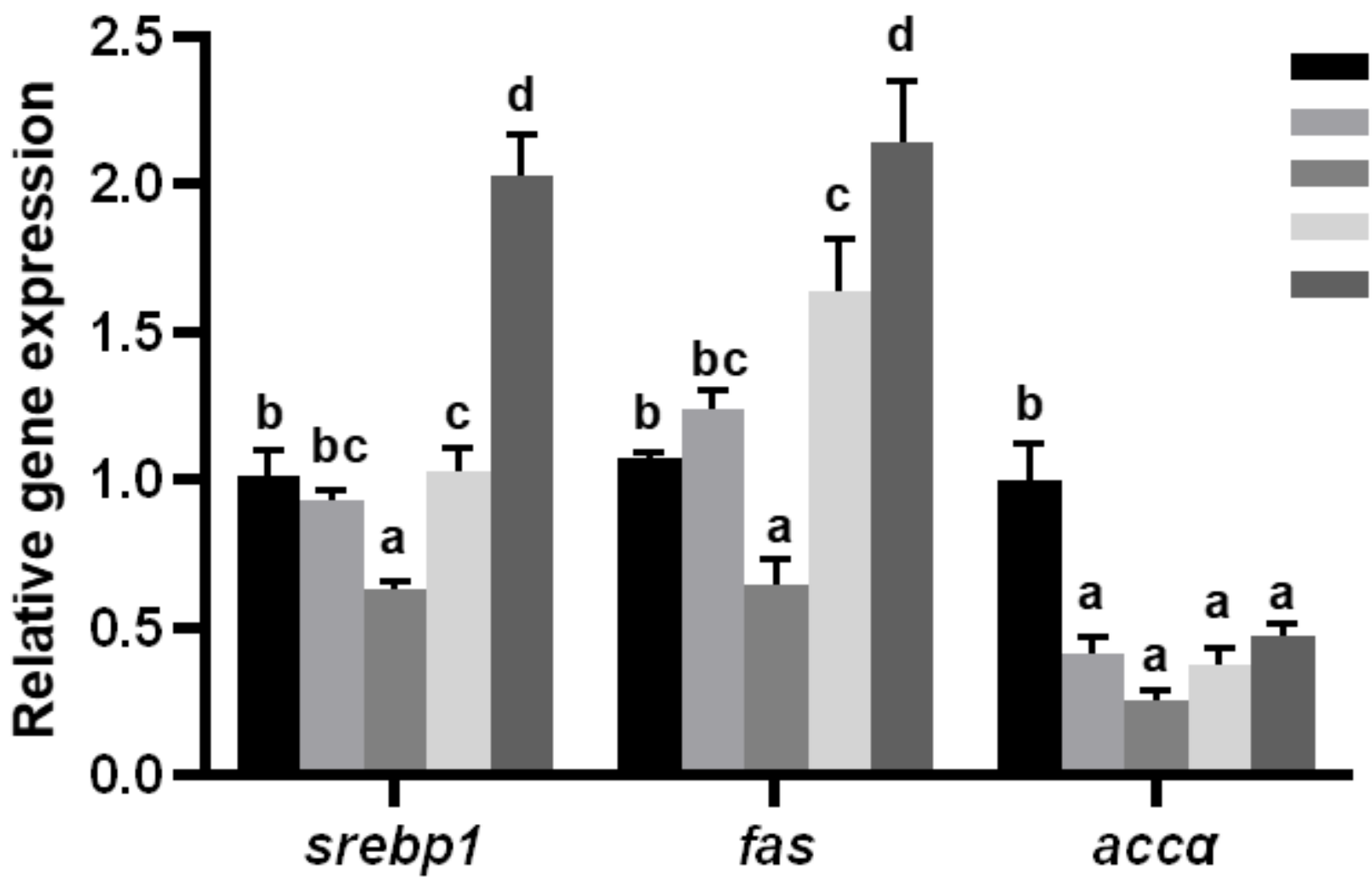

Figure 2 
The mRNA expression levels of genes involved in lipid synthesis (srebp-1, sterol regulatory elementbinding proteins- 1 ; fas, fatty acid synthase; acca, acetyl-coA carboxylase alpha). Values are presented as the means \pm SEM $(n=6)$. Different lowercase letters above the bars indicate significant difference $(P<$ 0.05).

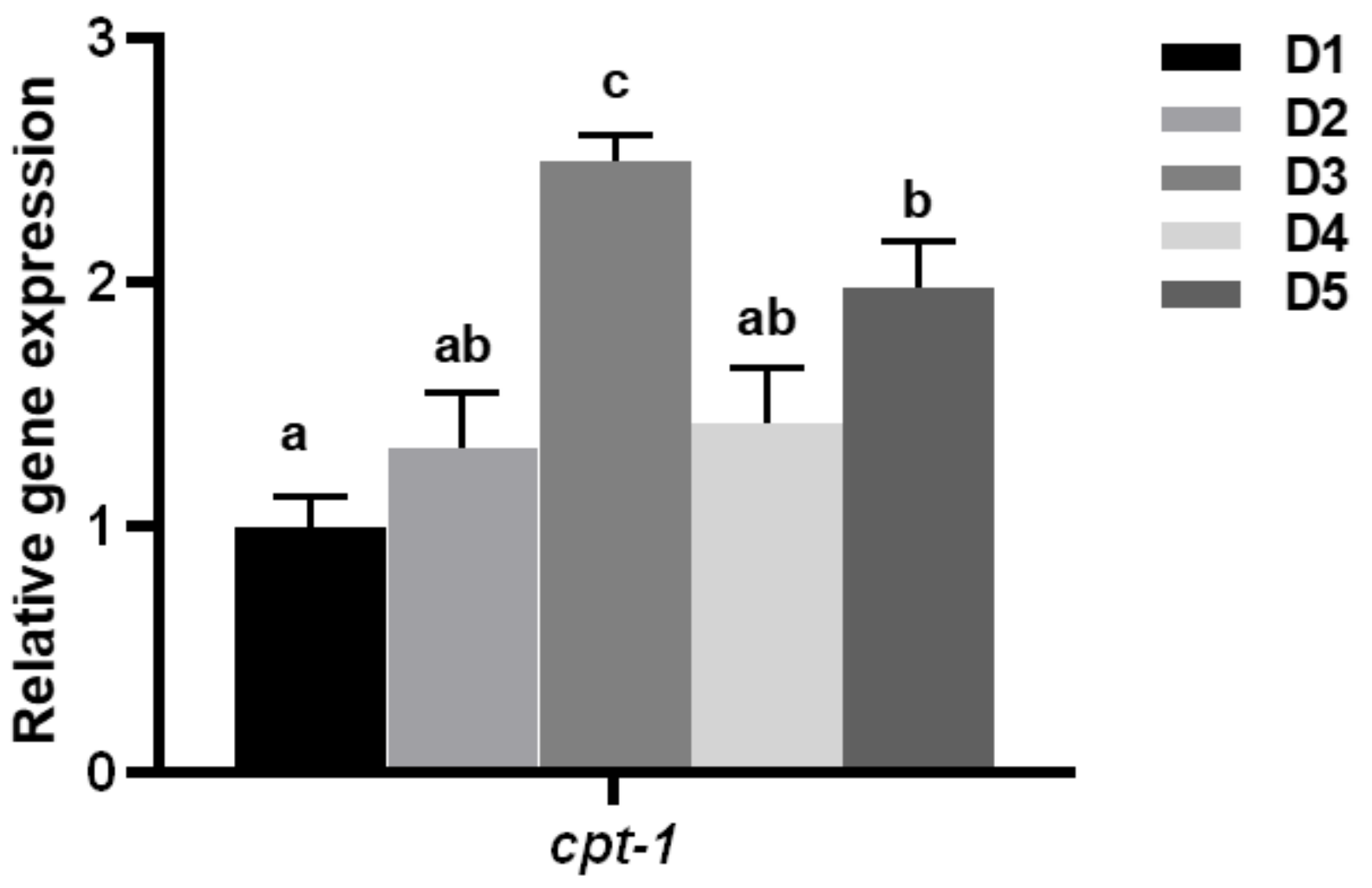

\section{Figure 3}

The mRNA expression levels of genes involved in fatty acidß-oxidation (cpt1, carnitine palmitoyl transferase). Values are presented as the means $\pm S E M(n=6)$. Different lowercase letters above the bars indicate significant difference $(P<0.05)$. 


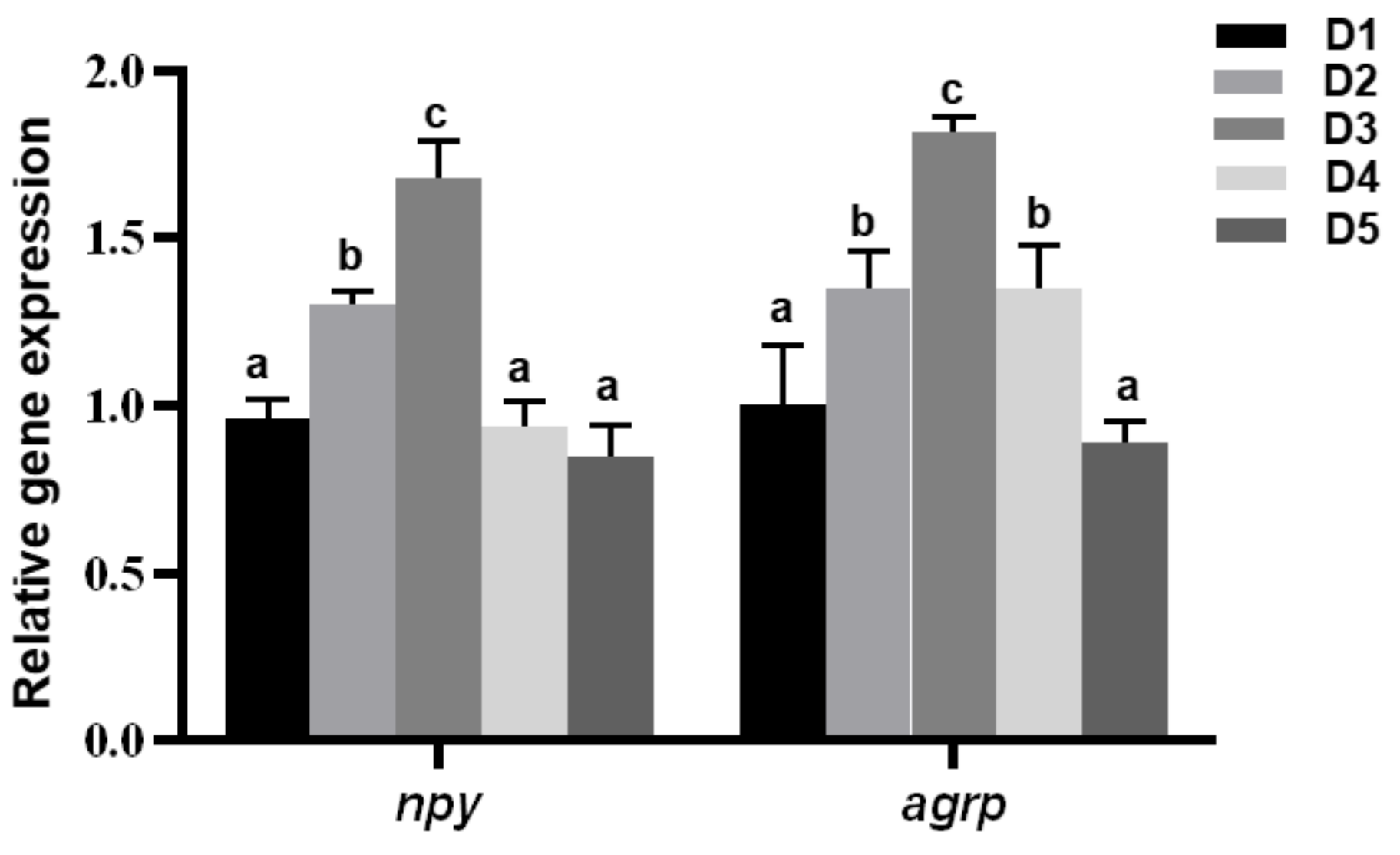

Figure 4

The mRNA expression levels of genes involved in appetite-promoting genes in the hypothalamus (npy, neuropeptide $Y$; agrp, agouti related neuropeptide). Values are presented as the means \pm SEM $(n=6)$. Different lowercase letters above the bars indicate significant difference $(P<0.05)$. 


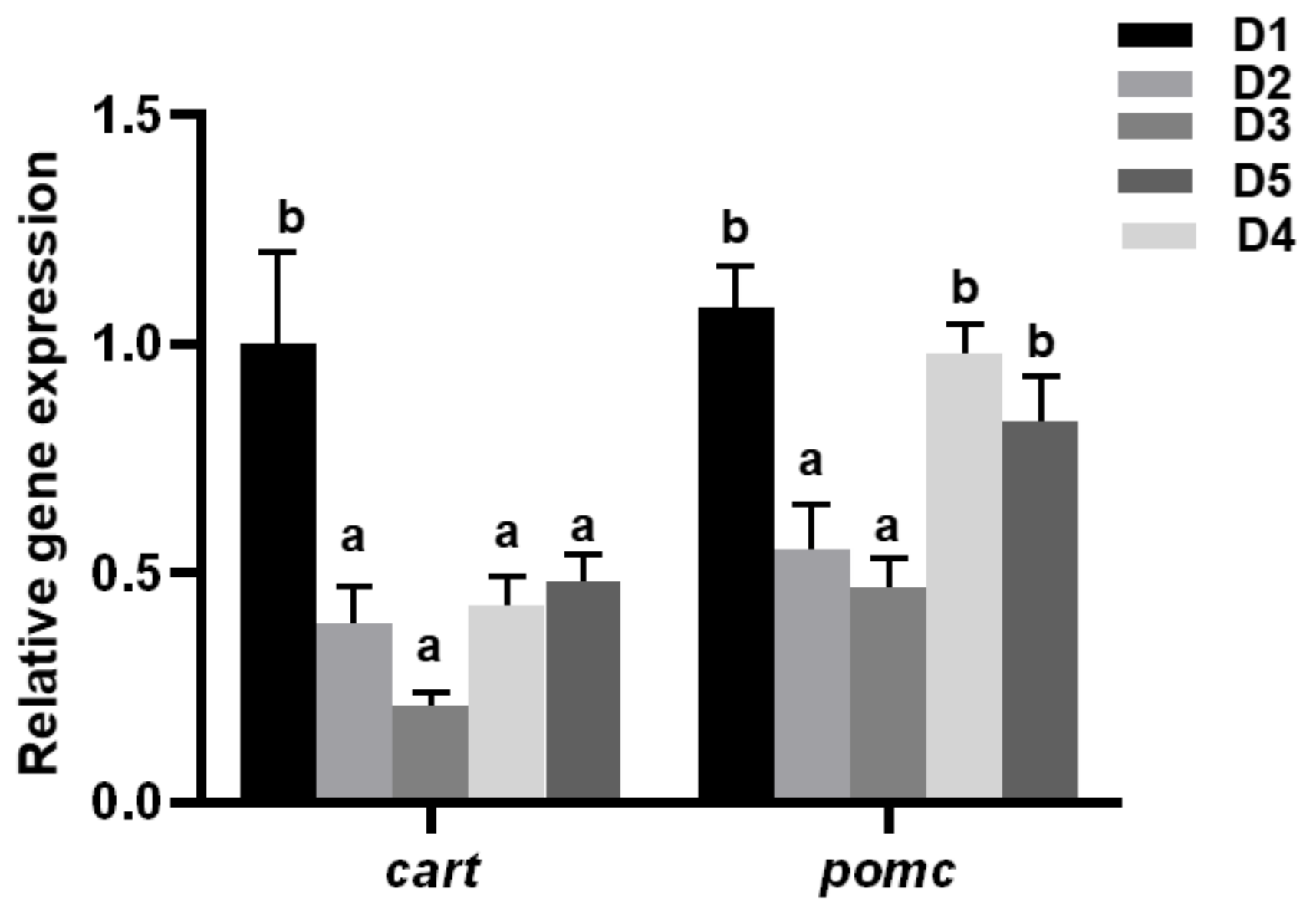

Figure 5

The mRNA expression levels of genes involved in appetite-inhibiting genes in the hypothalamus (cart, cocaine-and amphetamine-regulated transcript; pomc, proopiomelanocortin). Values are presented as the means \pm SEM $(n=6)$. Different lowercase letters above the bars indicate significant difference $(P<0.05)$.

D1

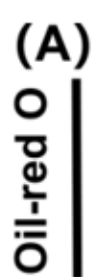

(B)

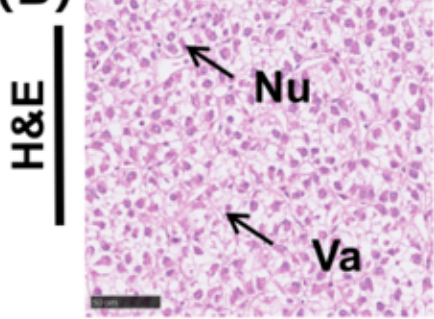

D2
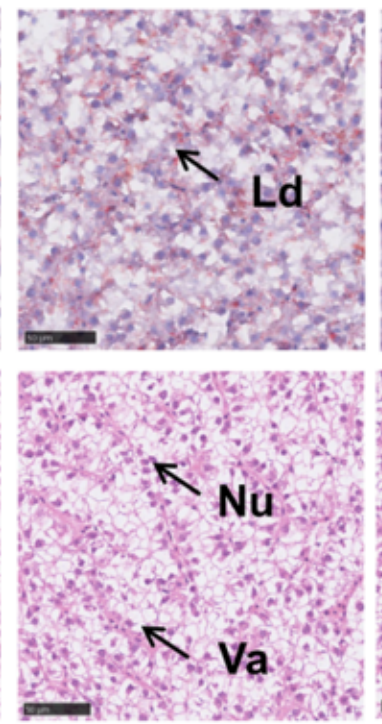

D3

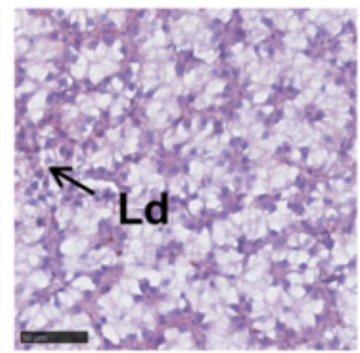

D4
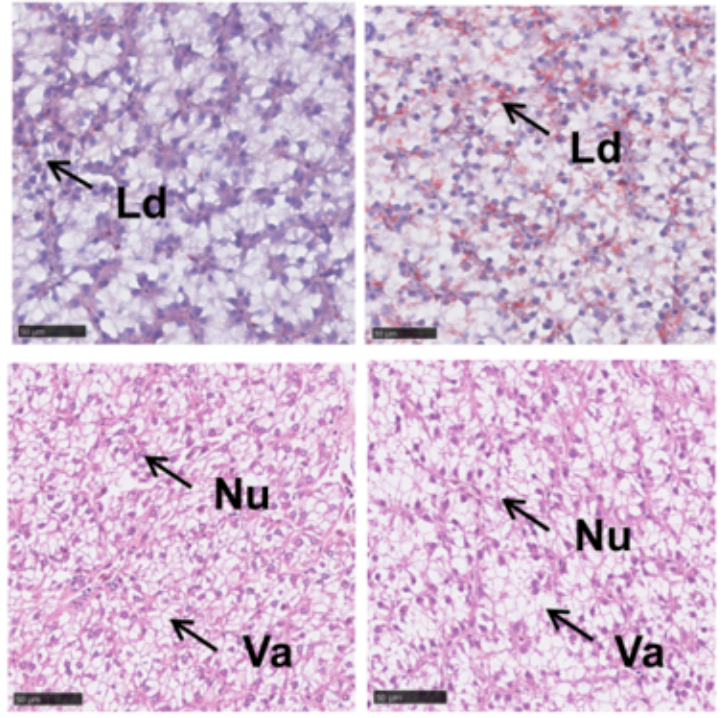

D5

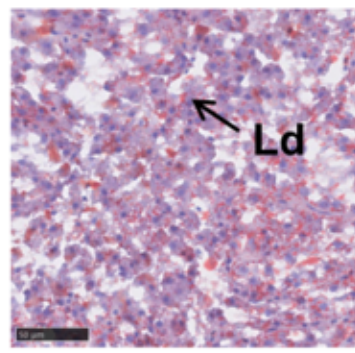

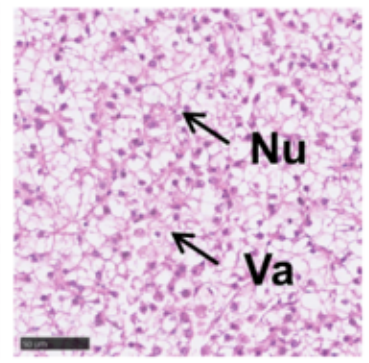

Figure 6 
Histology analyses of liver section and determination of hepatocyte inflammation. (A) Hepatic tissue section (40x magnification) of Oil Red $\mathrm{O}$ staining of Chinese perch fed with dietary different CHO: L level. (B) Hepatic tissue section (40x magnification) of hematoxylin and eosin staining of Chinese perch fed with dietary different $\mathrm{CHO}$ : $\mathrm{L}$ level. Lipid droplets appear red after staining Oil Red O, and the depth of color of the red stain and the amount of the lipid droplet were positively correlated with lipid content. The nuclei of hepatocyte appear blue and the vacuole present to be hyaline after staining hematoxylin and eosin, and the numbers of nuclei were negatively correlated with hepatic steatosis. Ld, lipid droplet; $\mathrm{Nu}$, nuclei; $\vee$ a, vacuole. 